\title{
Journal of Arts and Social Sciences
}

\author{
https://ojs.jass.pk
}

\section{Political Parties and their Participation in Democratic System Pakistan Dr. Zahid Yasin*, Iqra Jathol**, Dr. Muhammad Muzaffar***}

\author{
* Assistant Professor, Department of Political Science, Government College Women University Sialkot, \\ zahid.yaseen@gcwus.edu.pk. \\ **Ph.D Scholar, Government College Women University Sialkot, iqrajathol@gmail.com. \\ *** Assistant Professor, Department of Political Science, Government College Women University Sialkot, \\ muzaffarrps@gcwus.edu.pk.
}

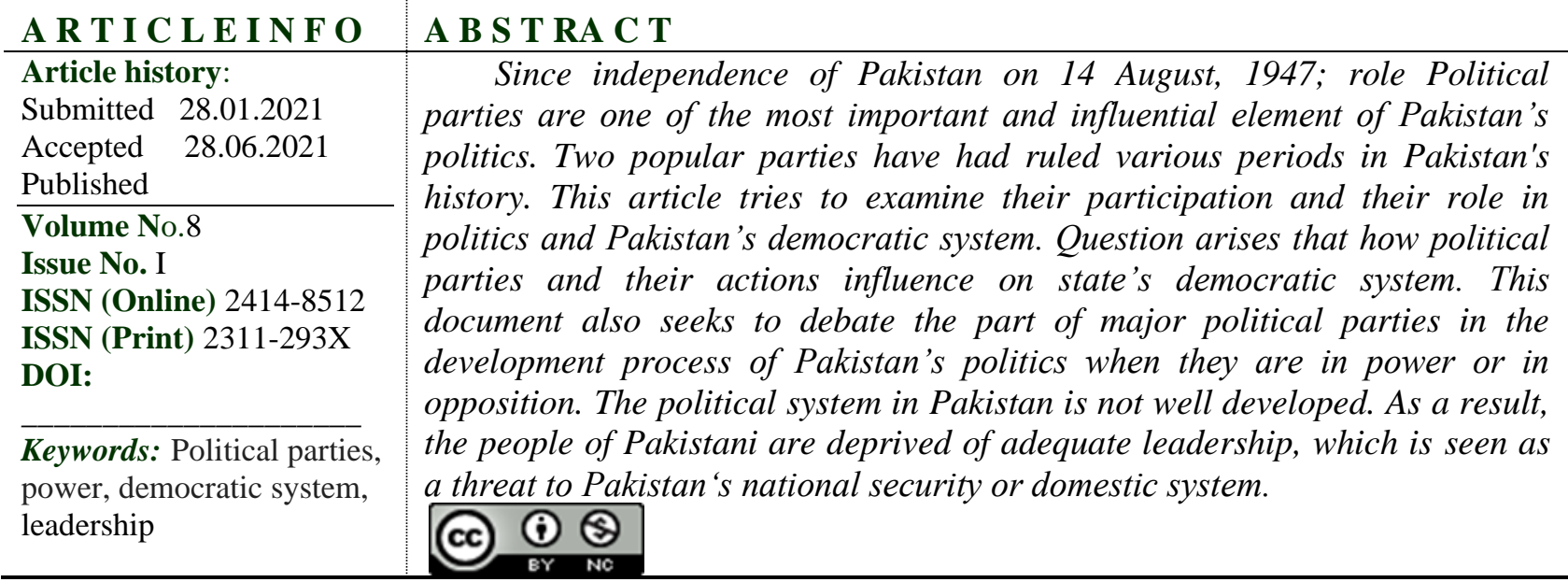

\section{Political History of Pakistan}

August 1947 has taken a main political modification on the world map after founding of Free states name: Pakistan and India on August 14 and 15 respectively. A longest British ruleof almost 150 years has been ended. (Siddiqi, 2012)."A large number of Muslims from the Indian part of the subcontinent have immigrated to Pakistan. About two million people were killed as a result of community violence and hatred between Sikhs, Hindus and Muslims. The majority of the victims were Muslims. Soon after gaining independence, Quaid-e- Azam Muhammad Ali Jinnah, the founder of Pakistan, became the first governor general of Pakistan. But he died in 1948. Quaid-e-Azam was the most influential person in the party (Muslim League) and enjoyed the full support of the Pakistani population. He was the only person who could unite all political leaders and ordinary people under one national identity, and his death had a profound impact on Pakistani politics. His successor, Liaqat Ali Khan, became prime minister and tried to fill the gap between Quaid and Azam, but was killed in October 1951" (Aziz, 2007).

The weaknesses of political parties is seen when Pakistani politics degraded in 1958 and Skandar Mirza took full advantage. At that time, there was only one choice to prevent parliamentary elections, namely the introduction of Martial law. At the end of the failure of the parties; a state of siege was proclaimed on October 7, 1958. Sikandar Mirza announced a "proclamation" repealing the constitution and explaining the state of the siege in Pakistan. The democratic phase of Pakistan between 1989 and 1999 proved to be shortlived, although many believed that democracy was finally established. G. Musharraf's military takeover in October 1999 and following developments, particularly the ban on two major national parties and Pakistan's democracies (PPP and PML) and the local election of less basic parties The holding shows a remarkable similarity with previous military governments, despite the formal return to parliamentary politics since the 2002 and 2008 general elections, the two elements are Pakistan's undemocratic Suggests that the conflict 
with the heritage is incredibly small (McCartney, 2011).

Pakistan became progressively independent during the Ayub regime because he was heavily reliant on establishment for managing political configuration. General Yahia Khan replaced Ayub Khan and ruled Pakistan for more than two years. From 1947 to 1958, no nationwide elections were held, as most politicians knew that voters would be rejected them in that situation so, they were held two indirect elections between 1958 and 1968, but were not held freely and fairly."Ayub Khan presented the first constitution of Pakistan. The presidential form of government was introduced and all power was entrusted to the President. A basic democratic system was established and only eighty thousand grass roots democrats were elected president. The army ruled Pakistan for more than thirty-four of Pakistan's sixty-four years of independence. Feudal landlords and the capitalist class have not contributed to the development of democracy in Pakistan". (Rizvi, 2011)."National elections took place again in 1977 and Z. A. Bhutto stood for a strong alliance of political parties (Pakistan National Alliance, PNA). Bhutto won the election and the ANP was able to secure only 36 of the 277 seats in the Pakistani National Assembly. The opposition said the elections had been rigged and started fighting the PPP government. Bhutto called on the army to restore public order and to negotiate with the ANP" (Jafri, 2002).

At last Ziaseized the govt. and "As a result, a new era of long-term martial law began, which ended in 1988 with the murder of Zia ul Haq. Benazir Bhutto, the daughter of Z.A. Bhutto came to power after the November 1988 elections with a majority of votes"( Rais, 1989). "The democratic era (1988-1999) alternated between B. Bhutto and Nawaz Sharif until 1999, when the general public was fed up with the democratic era and the corruption of politicians. In 1999 general dictator Pervaz Musharaf imposed the state of siege and ruled until 2008 with so-called democracy. The Pakistani people initially welcomed this change of government in the hope that the unjust economic, social and political system would be reformed, but after two years the Pakistani economy fell into disrepair" (Jalal, 1999).

Nawaz Sharif was appointed in 1993, and while in office, cases were filed against Butto and his family, and other leaders. A similar problem appeared on her next regime. The two parties PPP and PML-N mistreated and attempted to threat opposition parties by reporting suitcases to each other. The demonstration lasted until 1999, when the two parties tried to threat the opponent and the drama ended, Musharraf (military manager) took over democratic government in 1999. (Rounaq, 1972).

Because, the democratic phase of Pakistan between 1989 and 1999 proved to be short-lived. Where, many believed that democracy was finally established. In October 1999 General Musharraf's military takeover and several are following developments, in particular the ban on two major national parties and flag bearers of Pakistani democracy. The local elections against unfounded parties Organizations have shown significant similarities with the administration. Despite the official return to parliamentary politics since the 2002 and 2008 general elections, two factors suggest that conflict with Pakistan's undemocratic heritage may be less than one might believe. First, the military, in adopting the National Security Council's regulatory framework in 2004, successfully established a permanent and high-level role in elaborating national policy.Second, MMA religious parties have alienated traditional parties for almost a decade (from 1999 to 2008) and have more political legitimacy than ever. From a military perspective, PPP has been great targeted, the PPP, with its mass base and relatively greater hostility to the army, as well as its Sindhi leadership, posed the bigger threat.The Musharraf administration has also indicated a willingness to work with PML over PPP. During post-election exercises since 2002, PML-Q was created as a political support party from the conservative part of PML-Q (Ollapally, 2008).

PTI is only notable party of Pakistan which has wowed to end feudalism from Pakistan through land reforms. The party was launched after Imran Khan's successful drive to collect funds for his hospital of cancer treatment: named after the death of his mother, "Shaukat Khanum", who died of cancer. The party's objectives are to establish a modern Islamic State. The party declares its determination to make Pakistan a independent modern Islamic state which shell uphold the basic rights of all in habitants irrespective of class, caste, color, religion and ensure the peace (Jafri, 2002).

"Pakistani Justice Movement is the central political party in Pakistan, created in 1996 by former international cricket captain and current Pakistani Prime Minister Imran Khan. Following the 2018 general election, PTI is the ruling party in Pakistan and the largest party in the National Assembly of the ruling coalition"(wikipedia). 


\section{Political Parties}

In fact, political parties were born literally only a century ago. In 1850, none of the countries in the world (except the United States) had any political party in a modern sense. There were disagreements, popular clubs, philosophical societies and factions, but no actual parties. In 1950, political parties were active in most civilized countries and attempted to imitate other countries.

(Duverger, 1954) Modern democratic institutions cannot function successfully without political parties. Political system and Political parties of any country are reflectedsignificantrole for the effective modern Govt. Pakistan also belongs to that type of countries who have unsuccessful to reach their goals for political development. After more than 70 years of freedom, much of people still living problems of health care, sewerage, education, clean water, shelter and transportation. Now, in the age of globalization; many face daily joblessness,poverty,starvation, exploitation, cruelty, discrimination, police department atrocities, religious extremism,capitalism and feudalism (Khalid, 1966).

1. Political parties are not groups of people. It is very important that political party members are organized according to definite ideologies or welfares. So that, the party can be renowned from other parties ( Verma, 2006).

2. It is essential to political parties that they must have a relationship with their all supporters. Party leaders should maximum struggle to their popularity and the party must adopt constitutional means to seize power, to adopt its strategies and platforms, or to defend and encourage its exact benefits (Scholte, 2006).

After analyzing the political system of Pakistan, the personified environment of the policy is thoroughly linked to the domination of the elites. Maleeha said that:

There are two types of linkages in political party system, nominated with internal as well as external.

External links establish relations between political parties and national citizens. Maleeha also described how to establish and maintain external connections between political parties and their citizens. An external link is a link between asubordinator of the party and thepeople. She clarifies the relationship between parties and the general public. It moreover describes which groups are most influential at a particular party. On the other side PPP the largest political party of Pakistanis dominant party in Sindh. PPP has introduced its slogan Roti, Kapra, Makan (bread, clothe and house)). The party mainly targets poor and under privileged communities, especially the countryside areas of Sindh and also Punjab. PPPs will have a significant impact on the smallparts of Punjab and waste in Sindh. They are mainly going to use Sind.

\section{Internal linkage}

The internal link defines the affiliation and relationship among the members of particular political parties; the members of a party organization are connected via the internal link. So, is explained in more detail the establishment of such connections and the principles for a membership of a political party. "She discussed the question of what steps we need to take to maintain the internal link. Internal links explain the internal relationships and unity in each political party. Members of political parties are recruited based on internal links. In Pakistan, the inner bond between political parties depends on family politics, feudalism and nepotism. There is no specific rule for recruiting members of a political party. The only rule that can describe the recruitment of members is the importance of family relationships or the preference for everyone in the region. If a person is so famous in a particular area that they can get the voices of the people in that region, every political party will try to adapt to that person".(Lodhi, 2011).

\section{Representation ofParties in politics}

The Representatives of parties participating in elections in a particular region organize numerous rallies and processions (public meetings) in the respective region and appeal to the population of these marches. 
They also participate on TV shows and present them in terms of important events and topics. During these jalsas, presentations of participants the manifestations of their competing parties and appealeveryday with many attractive deals and public and valuable work they will do to improve the region after their representatives have been elected (Duverger \& Wagoner,1972).

A leader represents a particular group, region or number and Selects users from this group, region, or number of people and the selected political leaders are one of them (Pildat, 2009).

The population is small in some areas and there are insufficient representatives and it is so hard to protect them during the decision-making and even in populated areas, the problems are faced in overwhelming areas. The expressive representation has had a deep effect on Pakistan's political antiquity. Particularly, imaginative words founded on ethnicity, language, and religion and the impression of expression, the parties present candidates for each community. Theselected candidates formulate party announcements, perceive and pay attention to the requirements of the public. The strength of this system is that the total parliamentarian work in a very effectual way and generates a reliable legislative figure in unity with appropriate laws and principles a mid points.(Converse \& Pierce,1986). "In representation by population, representatives are elected by almost equal numbers of voters. In this process, the whole country is divided into more or less equal blocks of voters. In territorial representation, representatives are elected by area" ( Ankersmit, 2002).

\section{Appropriate leadership and Political development}

The political development process is the reconstruction or modernization for the benefit of the population in general. This process also makes it possible to raise public awareness for the progress of political establishments that are bright and able to meet common objectives and the mutual needs of citizens. As a result, an established political structure with its organizations, institutes and procedure contributes to progress. It can be useful for the progress of a healthy society on a national and global level. These institutions strengthen political power and the system to achieve political development goals. Adequate leadership can change the situation in Pakistan. However, neither party was able to provide adequate advice and identify people's needs and problems (Alavi, 1983). Ayub did not understand the extent in which his specific growth and policies carried almost social changes and, then, political demands (Jones, 2003).

The appearance of a two-party democracy system in the 1990s did not encourage the institutional formation of common collections and depreciated struggle. Zia has tried to setup more ideological approaches to the Pakistan government (Islamization). Subsequently, in early 1970s, oppressive institutions under the Butto administration reappeared and officially regained power in a 1977 military takeover. In the 1980s, the government was well governed, mobilized sufficient resources, and could be used efficiently sufficient to keep GDP at a sensible and reasonable pace. At last, the death of Zia, the rise of new liberalization, and global democracy forced Pakistan to return to competition party policy and neo liberal reform Programs that can understand. ( McCartney, 2011)“During 1988-1999, the PPP and the PML-N, along with their allies, remained in power twice time each. When a political party comes into government, they want more and more power. Every ruling political party wants to weaken its opponents. When Benazir in power, in 1988 the PML-N was in opposition. The PML-N was also in power in Punjab, Consisting of 60 percent of the province's population. Bhutto tried to de stabilize the Punjab government and made cases against opposition leaders. On the other hand, the opposition gave benefits to ruling members to enhance its power in parliament because they wanted to bring a vote of no confidence against the government. Considering the short life of civilian regimes, patronage politics rarely support the ruling party. Mostly political leaders change their parties after completing or at the end of its ruling tenure"( Ghazali, 1999).

\section{Family Politics}

In Pakistan, The worst example of family politics is seen in two popular parties. Parties try to maintain highest place in their parties and political system; they have mutually agreed to change the constitution."In the 18th amendment, they made changes to take the party. If the party leader believes that a particular party member does not represent the party, he can write to the speaker and have him removed. According to that amendment rule of intra, party elections have vanished. This amendment will help the authoritarian behavior of party leaders. The politics of the political parties in Pakistan is simply family politics. First of all, we 
discuss the PPP. Z.A Bhutto established the PPP in 1967 and after his death in 1979, his daughter Benazir Bhutto succeeded him as party leader. After her as sassination in 2007, her husband Mr. Asif Ali Zardari and her son Bilawal Bhutto Zardari are combined leaders of the party. The same situation is in the PML-N as it has had the same leader, Nawaz Sharif, since its establishment in 1988. Now his brother Shahbaz Sharif is Chief Minister of Punjab. Hamza Shahbaz, son of Shahbaz Sharif and Mariam Nawaz, daughter of Nawaz Sharif, are also in politics. No others have been given a chance to present these parties apart from family members"(Akhtar, 2013).

\section{Student's Politics}

Students have always remained as traditional advocates in Pakistan's politics and recycled to exercisecontrol but the parties cannotpreserve these "nurseries"appropriately. Pakistan had handled military rulesthroughout its history and during thatrules tried to weak democratic systemof the country. Therehave been adopted different policies to get chance. Occasionally, they disqualified political parties and apprehended workers in prison; when Zia ("a military dictator") challenged confrontation from the community. He has banned all the political events in country and stressed to "depoliticize the people progressively"as he believed that politically awareness and involvement could ruin his Govt. Because he has lessened from past students movements in Ayoub Khan's era and the military ruler has to leave the government. So, he has banned on "student unions", the country deprived the two of the major sources for generating political leaders and suporters also. After Zia in 1988-1999, the nominated Govt. was in powered but did not attention on that imperative and important issue. PPP announced to promote student unions, but could not do so. The student association was banned by the Musharraf administration. Currently, students must declare that they will not engage in political activities while studying ( Butt, 2009). Student policy was critical to the public visibility of Pakistan's politics and an instrument for mass communication of many traditional and marginal social movements. They promise to recruit newcomers and bring them into politics was a characteristic contribution to weak political parties and the unstable democratic system. The political Islamic movements were primarily the beneficiaries of the complicity of the state of siege, in order to take advantage of the possibilities of the Cold War and a proxy war between Soviet Russia and the United States ( Butt, 2009).

\section{Role of opposition in Pakistan: Critical and constructive}

Opposition parties with few seats after election sit in parliament "Government related functions like implement party and good governance and handle opposition and criticism. The USAID Political Party Development Assistance report discussed opposition as; in democratic political parties outside the government or ruling coalition have the responsibilities of providing loyal opposition to government. The opposition party or parties scrutinize the government's work, raise debates on important issues, and put questions to the prime minister and cabinet ministers in parliament to make them accountable for their actions"( Randall, \& Svåsand, 2002).

There have been shameful disputes between the two popular political parties in Pakistan in the last four decades. Opposition parties have always created an archy of the ruling party, so for example while the PML$\mathrm{N}$ took power and the PPP was in opposition in 1990-1993, the ruling party was forced to end the government. PPP President Benazir Bhutto commanded the opposition and did not well cooperate with PML-N. Similarly, while PPP was the governing party in 1990 and PML-N opposite, the PPP government had to face (Mohiuddin, 2007).

The PTI is the ruling party in those days and PML-N as well as PPP is the opposition parties. PML-N and PPP are now "trying to destabilize" the PTI govt. by putting pressure inmanyapproaches, with commencing objections movements against the PTI govt.by challenging its work in courts. The opposition parties organized complaints against the govt. to criticize their performances. They are doing so just to destabilize and deteriorate the govt.

"The government has faced criticism from the opposition. The opposition parties are organizing public meetings against the government. This opposition also helped in the restoration of the judiciary. In this process, the opposition came out on the roads alongside the ordinary people. They filed cases against the government in the Supreme Court. But we must give credit to the present opposition because they have learnt from the bad experiences of the past. The present opposition not only criticizes the government on its 
wrong activities but also supports the government on their actions of national interest, for example, supporting the government in the procedure of the 18th Amendment in the Constitution. The opposition also supported the government in the resolution against the Drone attacks and in closing the NATO supply after the attack on the ISAF troops on the Pakistani Check Post in the Mehmaand Agency" (Akhtar, 2013).

\section{Conclusion}

Mostly, Political parties in Pakistan are prepared in such a way that they reflect family politics, so that Pakistani people have no chance to proclaim them and to involve in politics or to win an election democratically. The political parties therefore lack the support of the majority, which led to greater discontent among the population. In Pakistan, the political candidates need to look outside the contracted benefits of religion and societal relationship. Voters must also be informed of their rights and obligations.

"Accountability" is more stable and functional and PTI has won election 2018 with the aim of justice and accountability. If any party or govt. is incapable to satisfy the public then and there it could be relieved at election time.

In the history of Pakistan's political culture, the opposition role is not justified. Opposition parties are not doing well. They usually try to destabilize the government or collect points instead of centering on actual complications. The cultural and political responsibility in Pakistan is interesting and doubtful. The ruling party believes that responsibility is justice and the opposition black mailed it. Opposition parties do not support the reigning parties. Instead of this, they also are frustrating and destabilizing the govt. The opposition party's only purpose is to weaken the ruling party's government to such an extent that it is forced to end its government. Opposition parties are doing this to get popular supports that will assistance them to develop the next dominant party. In democracy the opposition parties are vital and important part. So, these parties must establish disapproval to inquiry government strategies if they are in contradiction of the community's interest. The opposition parties should try to attraction the people's consideration and offering themself as a second choice through the election. Like PPP attained a part in elections using this slogan Roti, Kapra, Makan (bread, clothes, and house) by its democratic package, the PPP had attained a wide range of voters but failure to satisfy its supporters or voters.

\section{References}

Ahmed, I. (1998). State, nation and ethnicity in contemporary South Asia. A\&C Black.

Akhtar, N. (2013). Role of political parties in the democratic system of Pakistan.

Ankersmit, F. R. (2002). Political representation. Stanford University Press.

Aziz, K. K. (2007). Party politics in Pakistan, 1947-1958. Sang-E-Meel Publications.

Butt, I. H. (2009). Revisiting Student Politics in Pakistan. Bargad.

Converse, P. E., \& Pierce, R. (1986). Political representation in France. Harvard University Press

Duverger, M., \& Wagoner, D. (1972). Party politics and pressure groups: A comparative introduction. London: Nelson.

Duverger, Maurice. (1954), Political Parties: Their organizations and activity in the modern state. Paris, Methuen \& Co.

Ghazali, A. S. (1999). Islamic Pakistan, Illusions \& Reality. Eagle Enterprises

https://en.wikipedia.org/wiki/Pakistan_Tehreek-e-Insaf

Jafri, A. B. S. (2002). The political parties of Pakistan. Royal Book Co.

Jalal, Aysha. (1999) The State of Martial Rule: The Origins of Pakistan's Political Economy of Defense (Lahore: Sang-e-Meel Publications.

Khalid B. Saeed, (1966). 1965: An Epoch Making Year in Pakistan-General Elections and War with India‘. Asian Survey. Vol. 6. No.2

Lodhi, M. (2011). Pakistan: Beyond the" crisis State". New York: Columbia University Press.

McCartney, M. (2011). Pakistan-The political economy of growth, stagnation and the state, 1951-2009. Routledge.

Mohiuddin, Y. N. (2007). Pakistan: a global studies handbook. ABC-CLIO.

Ollapally, D. M. (2008). The politics of extremism in South Asia. Cambridge: Cambridge University Press.

Pildat (2008) Citizens' March, 16 Report March, 2009), p(17.0).

Rais, R. B. (1989). Pakistan in 1988: from command to conciliation politics. Asian Survey, 29(2), 199-206. 
Randall, V., \& Svåsand, L. (2002). Introduction: the contribution of parties to democracy and democratic consolidation. Democratization, 9(3), 1-10

Rizvi, H. A. (2009). Political Parties and Fragmented Democracy. Pakistan: Reality, Denial, and Complexity of its State.

Rizvi, H. A. (2011). Democracy in Pakistan. Panorama: Insights into Asian and European Affairs is a series of occasional papers published by the Konrad- adenauer-stiftung's "Regional Programme Political Dialogue Asia/Singapore".p,117

Rounaq Jahan, (1972). Pakistan: failure in national integration. New York: Columbia University Press.

Scholte, J. A. (2006). Political parties and global democracy. Global political parties, 12-38

Siddiqi, F. H. (2012). The politics of ethnicity in Pakistan: the Baloch, Sindhi and Mohajir ethnic movements. Routledge.

Verma, M. (2006). Political Parties and Party System in Pakistan. Deep and Deep Publications. 